Balashov, E., Pasicichnyk, I. \& Kalamazh, R.(2021). Metacognitive awareness and academic self-regulation of HEI students, International Journal of Cognitive Research in Science, Engineering and Education (IJCRSEE), 9(2), 161-172.

Original scientific paper

UDK:

159.953.072-057.875

Received: March, 18.2021.

Revised: April, 06.2021.

Accepted: May, 05.2021.

doi: 10.23947/2334-8496-2021-9-2-161-172

\title{
Metacognitive Awareness and Academic Self-Regulation of HEI Students
}

\author{
Eduard Balashov*1 (D), Ihor Pasicichnyk ${ }^{1}$ (D), Ruslana Kalamazh ${ }^{1}$ \\ 1Department of Psychology and Pedagogy, National University of Ostroh Academy, Ostroh, Rivne Region, Ukraine \\ e-mail: eduard.balashov@oa.edu.ua; oa@oa.edu.ua; ruslana.kalamazh@oa.edu.ua
}

\begin{abstract}
The presented manuscript has analysed the theoretical aspects of the concepts of metacognitive awareness and academic self-regulation of HEl students. A theoretical essence of the mentioned above phenomena has been theoretically studied. The role and importance of metacognitive awareness and its components for the learning efficiency and academic selfregulation of $\mathrm{HEl}$ students have been described. It has been determined that such a metacognitive characteristic of personality as metacognitive awareness determines not only the organization of mental and behavioral processes, but also relates to the academic success of the subject of learning activity - student. The results of empirical research with the use of Questionnaire "Academic Self-Regulation" by R. Ryan \& D. Connell, Questionnaire "Metacognitive Awareness Inventory" by D. Everson \& S. Tobias, G. Schraw \& R. Dennison's questionnaire "Metacognitive awareness", and correlation analysis with the use of the Pearson's and Spearmen's rank correlation coefficients, have proved that students with a high level of metacognitive awareness (involvement in activities) have high performance on the basis of identified and internal self-regulated learning activities. The students of this type are more autonomous in conducting their self-regulated learning activities, developing their metacognitive abilities, such as metacognitive knowledge, metacognitive monitoring, metamemory and meta-thinking. Summarizing the results of theoretical analysis and the empirical data evaluation, we can conclude that the learning behavior of modern student youth has been dominated by dependent types of self-regulation.
\end{abstract}

Keywords: metacognitive awareness; academic self-regulation; learning efficiency; HEI students.

\section{Introduction}

Reformation of the current national system of higher education, daily increase of received information and necessity of use larger amount of it every day have caused the emerge of negative personal indicators in functional and cognitive spheres of a personality. Stressogenic situations require acquisition of new knowledge and competencies by students, developing new approaches to solutions of the problems connected with them. Introduction of the European educational standards require comprehensive approach to the issues of studying cognitive and metacognitive student's abilities, their metacognitive awareness during learning process, correlation and interdependence between their metacognitive abilities and academic motivation and efficiency.

The issue of the study of metacognitive abilities of the individual is extremely relevant due to the insufficient level of generalization and development of methods for diagnosing the metacognitive sphere of the individual. This issue is especially relevant in the context of studying the intellectual activity of students in the context of their academic success. Assimilation of educational material, performance of educational tasks, achievement of success in educational process demands activation not only of cognitive processes of students, but also their metacognitive abilities which allows analyzing a course of educational activity, cognitive methods and strategies, and, if necessary, correcting them. Students are the subjects of their own learning activities, and they need to learn to function effectively and fully in the educational and socio-cultural environment. An important factor influencing success is the students' learning motivation, which plays a significant role in their learning activities. Given that students' metacognitive abilities and learning motivation largely determine learning efficiency and success, we find it significantly relevant and appropriate to study the relationship between students' metacognitive awareness and their academic performance.

A large number of scientists have carried out the study of motivation. Metacognitivism is a relatively

"Corresponding author: eduard.balashov@oa.edu.ua

(C) 2021 by the authors. This article is an open access article distributed under the terms and conditions of the Creative Commons Attribution (CC BY) license (https://creativecommons.org/licenses/by/4.0/). 
new direction in psychological science, and researching this sphere is very relevant at this stage of its development (Flavell, 1976). Metacognitive abilities of personality and educational motivation have been studied by such scientists as Andrade and Heritage (2017), Bandura (1997), Brown, Andrade and Chen (2015), Dweck (1999), Ryan and Deci (2001), Karpov (2012), Flavell (1976; 1987), Schraw and Moshman (1995), Schraw, Crippen and Hartley (2006), and many others. Poshekhonova and Karpov (2014), Balashov et al. (2020) have proved its correlation with learning motivation and personal metacognitive abilities.

Among the modern Ukrainian scientists studying the issue of academic success and motivation of educational activities, we can distinguish the works of Zasekina (2015) - psychological determinants of students' academic success, Khomulenko and Dotsevych (2014) - metacognitive processes of personality, Savchenko (2016) - reflexive competence in the educational process, Pasichnyk and Maksymenko (2010) - metacognitive activity of students and metathinking, Radchuk (2015) - self-actualization and self-realization of students in educational activity, Pasichnyk, Kalamazh and Augustyuk (2014), Voloshyna (2014), Balashov (2017) and Tkachuk (2018) - metacognitive processes in learning, Yalanska (2018) independent work of students in the context of learning motivation), Kreidun, Polivanova and Yavorovska (2018) - satisfaction with studying in ZVO as a factor of professional self-efficacy of students and many others.

Dweck, who identified two types of implicit theories of intellect, studied it in the context of metacognitivism. The essence of the first type was that intellect is a constant little-variable feature, and in the second one, intellect was considered as a personal feature that could be developed (Dweck, 1999). One of the most important concepts of metacognitive abilities in psychology is the concept of intelligence Kholodnaya (2019). In particular, she has identified the metacognitive experience of a person as the basis for the regulation of effects in the work of intelligence. This has included four types of mental structures that carry out self-regulation of intellectual activity: involuntary intellectual control, which provides cognitive styles; arbitrary intellectual control, i.e. abilities aimed at setting goals, determining ways to achieve them and the sequence of actions and controlling results; metacognitive awareness, i.e. the level and type of introspective human ideas about their individual intellectual capabilities; and open cognitive position, i.e. variability of subjective ways of perception (Kholodnaya, 2019).

Motivation of students' learning activity consists of a set of factors that determine the self-regulation of this activity. We share the level approach to determining the factors of motivation of the individual, which has been set out in the theory of self-determination (autonomy) by Ryan and Deci (2001). The authors have defined such levels of motivation as extrinsic or external, when behavior and activities are determined by rewards and punishments; introjected with behavior determined by partially mastered rules and requirements; identified when behavior is determined by a sense of personal choice of the specified activity, previously regulated from the outside; intrinsic or internal with interest in the activity. Students' academic success is determined, according to this theory, by intrinsic motivation, which has been based on the need for competence (choosing the optimal difficulty of tasks, the presence of positive feedback) and self-determination (autonomy, internality of personality) (Ryan and Deci, 2001).

\section{Diagnostics of metacognitive awareness}

The urgent problems of the modern system of higher education are determination the level of metacognitive awareness of students and studying the possibility of direct inclusion of metacognitive knowledge in the process of their cognitive activity. In modern psychological science, there has emerged a completely new glossary of concepts such as "metacognition", "metathinking", "metacognitive experience", "metacognitive monitoring" and so on. The use of these cognitive processes in learning has set the new requirements and standards for students and teachers, as well as for the educational process in general. Within the new paradigm of education, it has been assumed that the teachers in their work should use new educational, technological, methodological and didactic approaches aimed at creative developing the individual personal characteristics of students and encouraging them to develop efficient metacognitive awareness and involvement in learning activities.

Modern higher education has been designed to ensure equal access to the best educational resources and practices for all participants of the educational process, and ensure the formation of an intelligent, competent and competitive professional at the labor market. In order to prepare a student to function in such conditions, academic knowledge, functional skills, personal and communicativeorganizational competencies are not enough. It is necessary to develop their completely new personal characteristics, such as metacognition and metacompetence.

Studying the phenomenon of metacognitive awareness of students is a prospective scientific 
direction in the field of educational psychology, because the success of awareness plays an important role in all areas of intellectual activity of students, and allows the students to carry out cognitive activities effectively while studying at $\mathrm{HEI}$. It is worth remembering that the student is a subject of educational activity and must consciously regulate this activity through the conscious use of cognitive abilities. It is understood that the student's own conscious activity ensures success in educational activities.

Recently, along with the extremely rapid information technology development of society, the importance of self-realization of the individual in learning, their ability to acquire new information effectively and consciously, analyze and update it through the prism of individual and personal qualities, has increased significantly. That is why there is an urgent need to determine scientifically the psychological features of metacognitive awareness of students and their place in the structure of metacognitive activity. The relevance of the proposed topic has also been determined by the point of view that this activity can be developed during the life of the individual, and thus, increase the efficiency of the individual's entire learning process.

The study of the concepts of metacognition and metacognitive activity has been a relatively new area of psychological science and has combined the study of several areas. Study of metacognitivism began in the works of $\mathrm{J}$. Flavell in the 70 s of the past century. The scientist defined metacognition as a set of human knowledge about the features of their own cognitive activity and ways to control it. He identified three main stages of metacognitive processes that developed mainly through the search for information, its actualization and systematization (Flavell, 1976). Metacognitive abilities of the individual and their connection with academic success have been studied by such scientists as Andrade and Heritage (2017), Pintrich and Zuszo (2002), Schraw and Dennison (1994), Shunk and Greene (2018) and others.

In the works of psychologists, the concept of metacognition is usually defined by describing its structure. M. Kholodnaya in her theory of intelligence identified two of its main components: metacognitive knowledge (knowledge of cognition) and metacognitive processes (monitoring and evaluation, control and regulation of cognition) (Kholodnaya, 2019). Schraw and Moshman (1995) identified the main directions of formation of metacognition in the educational activities of students, namely: encouraging students to understand the importance of the development of metacognition; improving knowledge about cognition; improving the regulation of cognition; creating conditions that stimulate students' metacognitive activity. Scientists claimed that the ability to self-regulate own learning activities increases the productivity of cognitive activity, as well as the causes of their own failures in this activity (Schraw and Moshman, 1995). Many authors have considered metacognition as the necessary and effective tool for the formation of students' metacognitive knowledge in the learning process. American psychologists Pintrich and Schunk (2002) believed that metacognitive knowledge should be included to the learning process and taught for the students as an important part of their learning at HEI.

The generalized characteristics of the components of the structure of a personality's metacognitive knowledge have been presented at Table 1 (Babikova et al., 2018). Obviously, metacognitive knowledge consists of such components as general knowledge about knowledge, knowledge about one's own learning, knowledge about cognitive tasks. Instead, metacognitive processes consist of evaluation and monitoring, as well as control and regulation. 
Balashov, E., Pasicichnyk, I. \& Kalamazh, R.(2021). Metacognitive awareness and academic self-regulation of HEl students, International Journal of Cognitive Research in Science, Engineering and Education (IJCRSEE), 9(2), 161-172.

Table1

Structure of Personal Metaknowledge

\begin{tabular}{|c|c|}
\hline $\begin{array}{l}\text { Metacognitive } \\
\text { knowledge }\end{array}$ & Components \\
\hline $\begin{array}{l}\text { General knowledge } \\
\text { about knowledge }\end{array}$ & $\begin{array}{l}\text { - declarative knowledge about cognitive strategies, methods and } \\
\text { techniques of memorizing, understanding, solving problems etc.; } \\
\text { - procedural knowledge as to how to use cognitive strategies; } \\
\text {-conditional knowledge, how and when to use certain strategies. }\end{array}$ \\
\hline $\begin{array}{l}\text { Knowledge about } \\
\text { cognitive tasks }\end{array}$ & $\begin{array}{l}\text { - awareness of the complication levels of various learning tasks; } \\
\text { - awareness about relevance of certain cognitive strategies to various } \\
\text { learning tasks; } \\
\text { - awareness of the use of learning technologies depending on the situation } \\
\text { and main social and cultural norms and traditions. }\end{array}$ \\
\hline $\begin{array}{l}\text { Knowledge about own } \\
\text { learning }\end{array}$ & $\begin{array}{l}\text { - awareness of strengths and weaknesses, peculiarities of own learning; } \\
\text { - awareness of own motivation знання про власну мотивацію. }\end{array}$ \\
\hline $\begin{array}{l}\text { Metacognitive } \\
\text { processes }\end{array}$ & Components \\
\hline $\begin{array}{l}\text { Evaluation and } \\
\text { monitoring }\end{array}$ & $\begin{array}{l}\text { - evaluation of the level of complication of the cognitive task execution; } \\
\text { - monitoring of understanding in the process of learning; } \\
\text { - feeling "knowledge", understanding the situation when "I know", but "I can't } \\
\text { remember"; }\end{array}$ \\
\hline Control and regulation & $\begin{array}{l}\text { - planning of activities; } \\
\text { - making a decision about the choice of a strategy for solving a concrete task } \\
\text { or changing the strategy during execution of the tasks; } \\
\text { - division of resources, time, efforts; } \\
\text { - control and regulation of motivation, emotions. }\end{array}$ \\
\hline
\end{tabular}

In our work, we have assumed that such a metacognitive characteristic of personality as metacognitive awareness determines not only the organization of mental and behavioral processes, but also relates to the academic success of the subject of learning activity - student. Despite the large number of studies of the psychology of metacognitive processes conducted in the last decade by domestic and foreign scientists, they do not cover all the potential problems of metacognition, so special attention needs to be paid to studying the links between the components of student metacognitive activity and metacognitive awareness (Karpov, 2012).

The most important modern task of higher education is the formation of students' ability to organize their cognitive activity independently, use their own cognitive abilities and strategies skillfully, analyze the course of educational activities, adjust and correct them if needed. The peculiarities and structure of metacognitive abilities of a person, metacognitive awareness and its connection with educational motivation and self-regulated learning of students have been studied insufficiently, which necessitates a deeper study of these phenomena and their relationships in student learning activities.

\section{Materials and Methods}

The empirical study we conducted was to diagnose correlation between the metacognitive awareness and academic self-regulation of the subjects of learning activity - HEl students. The study was conducted at the National University of Ostroh Academy, and empirical data was collected during January-March, 2021. The sample was formed by a spontaneous method from the full-time students of all years of study. Thus, 76 respondents ( 14 males and 62 females) regardless of major, aged from 17 to 22 years $(M=19,88, S D=1,664)$ participated in the study.

To complete the empirical research, we have used the following methods.

1. Questionnaire "Academic Self-Regulation" by Ryan and Connell (1989), which contained of 32 statements aimed at at evaluating the level of development of external regulation (extrinsic or external motivation of educational activities), introjected regulation, identified regulation and internal motivation (intrinsic or internal motivation) (Yatsiuk, 2008).

2. Questionnaire "Metacognitive Awareness Inventory" by S. Tobias \& D. Everson, and particularly one of its scales - metacognitive awareness. The methodology has been designed for evaluating the level 
of formation of metacognitive behavior in general, and using the mentioned scale allowed to determine the student metacognitive involvement in the activity. The questionnaire aimed at studying the four blocks of metacognitive qualities of personality, namely: metacognitive involvement in activities, use of strategies, action planning, self-examination. The questionnaire contains 20 statements that are evaluated on a standard Likert scale (Tobias and Everson, 1997).

3. Analysis of empirical indicators of metacognitive awareness has been conducted with the use of $G$. Schraw \& R. Dennison's questionnaire "Metacognitive awareness". It included 52 questions, which allowed to measure two components of metacognition: metacognitive knowledge and metacognitive processes, which diagnosed the level of metacognitive awareness of students. We chose this methodological diagnosis because the use of this questionnaire was quite simple and convenient (17 questions belonged to the category of metacognitive knowledge (procedural, declarative and conditional), 35 questions to the category of metacognitive processes (information management strategies, debugging strategies, planning, monitoring understanding, evaluation)). This questionnaire is well known and widely used by psychologists, easily allows you to diagnose the level of these two components of metacognitive activity. The scale for each answer was rated from 0 (strongly disagree) to 5 (strongly agree) points (Karpov and Skityayeva, 2002).

To process the quantitative and qualitative data we obtained after psychodiagnostics, we used the methods of mathematical statistics: finding averages, Pearson's correlation coefficient and Spearman's correlation coefficient. All data of this experiment were processed using SPSS, where the results were lower than the level of 0.5 . Correlation is a statistical indicator that allows determining and evaluating the probabilistic relations between two variables. It should be noted that the peculiarity of the probabilistic relation is that one value of a certain variable corresponds to a number of values of another variable. The presence of a positive direct correlation indicated that the increase of indicator of one value cause the increase of such indicator of another one. The accuracy and validity of the research conducted was ensured by representativeness of the sample, the use of the methods relevant to the topic, aim and tasks of the study, the use of quantitative and qualitative analysis of the received empirical data by using the following methods of mathematical statistics. We have set a hypothesis that there is a positive correlation between the metacognitive awareness of HEI students and their academic self-regulated learning.

\section{Results}

The average indicators of motives of the student motivation for learning self-regulation according to the results of the Questionnaire "Academic Self-Regulation" by R. Ryan \& D. Connell have been presented in the table 2. It is easy to see that students have an average level of academic self-regulation according to the scales of external regulation, introjected regulation and internal motivation. This indicator differs only for the scale of identified regulation, where high level of identified regulation prevails, which indicates that university education is not just a formality or a compulsory necessity for them, and that in the student age of modern youth behavior is largely determined by a sense of the own desires and wills, as well as own conscious choice. Young people with a high identified level of self-regulation are guided in the regulation of educational activities by learned patterns of behavior. They are sensitive to positive assessments from reference persons, authorities, shows initiative and self-confidence in performing activities.

Table 2

Indicators of motives of student self-regulated learning activity (according to the Questionnaire "Academic Self-Regulation" by R. Ryan \& D. Connell)

\begin{tabular}{lccc}
\hline \multicolumn{1}{c}{ Level } & Low, \% & Average, \% & High, \% \\
$\begin{array}{l}\text { Indicator of academic } \\
\text { self-regulation }\end{array}$ & & & \\
\hline External regulation & 2,5 & 57,5 & 40,0 \\
Introjected regulation & 5,0 & 65,0 & 30,0 \\
Identified regulation & 2,5 & 32,5 & 65,0 \\
Internal motivation & 5,0 & 55,0 & 40,0 \\
\hline
\end{tabular}


The relatively low rate of high level of external student self-regulation has confirmed the previous conclusions and indicated a relatively active subjective position of students in relation to their own learning activities. High indicators of average and high level of self-regulation have confirmed the idea that students have mostly inflated demands on themselves, guided in their educational activities mainly by introjected norms and guidelines. High level of introjected regulation is present among such students who have well mastered the norms and requirements of the socio-cultural environment, i.e., for whom higher education is the norm, the presence of a profession is a necessity and so on. Quite a significant indicator of medium and high level of intrinsic or autonomous (internal) self-regulation in students has showed that they have their own motivation to learn, i.e., characterizes these students as proactive, responsible, active, selforganized, creative in solving educational problems.

The next step was to evaluate the level and features of metacognitive involvement in the activity of students. First of all, we analyzed the obtained empirical data with the use of Metacognitive Awareness Inventory - MAI (by D. Everson \& S. Tobias). According to the results presented at the figure 1, the average sample value was $M=31.4$.

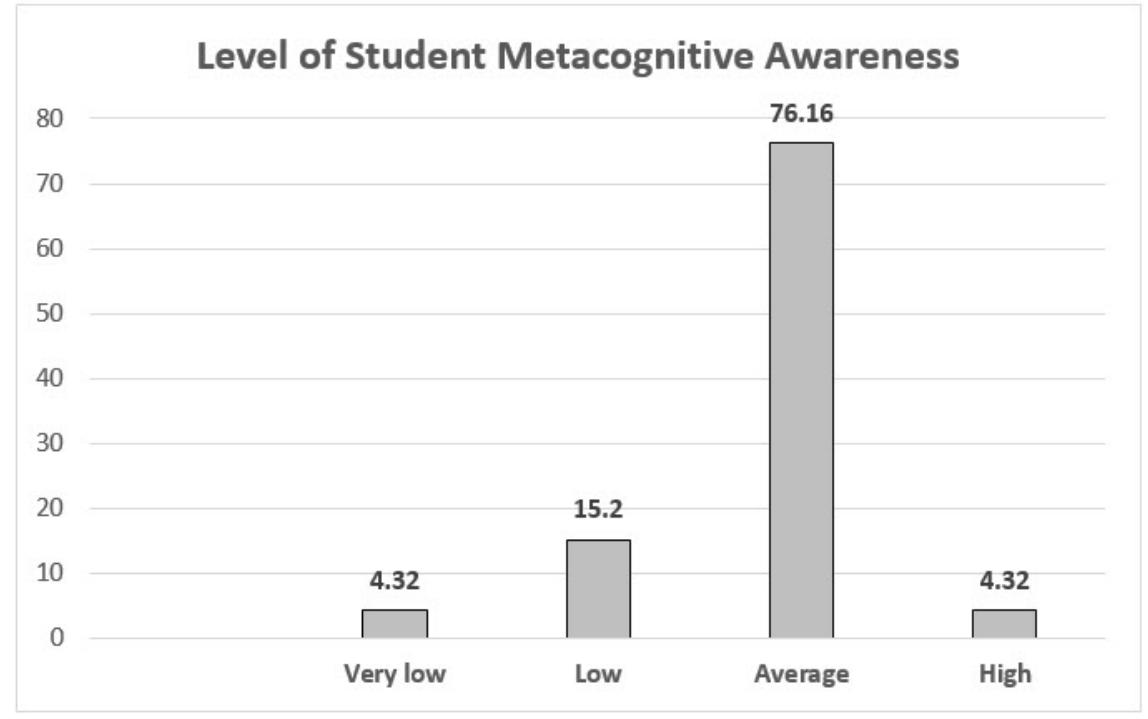

Figure 1. Levels of Student Metacognitive Awareness according to the results of "Metacognitive Awareness Inventory - MAl" (by D. Everson \& S. Tobias), \%

It can be concluded that the respondents have showed the average level of metacognitive awareness (involvement in activities). The analysis also shows that $4.32 \%$ of respondents have a low and high level of metacognitive involvement in activities, $15.2 \%$ - an average level, and the largest share $(76.16 \%)$ of respondents have an average level of metacognitive involvement in activities.

It is easy to see that the average level of metacognitive awareness (involvement in activities) has prevailed among students (above $78 \%$ of all sample). These students can be characterized as the ones usually having a high level of executive discipline, exemplary and diligent training, easy to work with reputable teachers. At the same time, they try to avoid depleting their own resources during the learning process, trying to find the most effective solution to the problem.

Students with a high level of metacognitive awareness can be described as original, flexible and creative, usuall trying to make free choices in their studies. They have their own point of view on every controversial issue, do not pay too much attention to the problems that harm their learning. Such students usually have well-developed metacognitive abilities and metacognitive incusion to larning activities. Our study has showed very a small number of such students (only $4.32 \%$ of respondents).

Also, a very small part of students has a low level of metacognitive awareness (4.32\%). This can be explained, from our point of view, by to the sensitivity of the student age, when they consider themselves to be the subjects of their own cognitive and intellectual activities, which consciously helps them to intensify educational activities. However, it can be noted that such students are mostly passive in the learning process, do not really strive for high results and care about the learning efficiency. Their activities are largely determined by the circumstances caused in surrounding socio-cultural environment, and they find it difficult to focus on one kind of learning activity.

The division of respondents into four groups according to the levels of metacognitive awareness 
has showed that almost $20 \%$ of students have very low and low levels of metacognitive awareness, and average and high levels are characterized for among above $80 \%$ of all respondents (Table 3 ). The highest indicator of the efficiency has been determined for the average level of metacognitive awareness $(84,9$ points), as well as for the indicator of MAI $(76,2 \%)$.

Table 3

Levels of students' metacognitive awareness

\begin{tabular}{|c|c|c|c|c|c|c|c|c|}
\hline \multirow[t]{2}{*}{$\begin{array}{c}\text { Level of metacognitive } \\
\text { awareness }\end{array}$} & \multicolumn{2}{|c|}{ Range } & \multicolumn{2}{|c|}{$\begin{array}{c}\text { Average } \\
\text { indicator of } \\
\text { metacognitive } \\
\text { awareness }\end{array}$} & \multicolumn{2}{|c|}{$\begin{array}{l}\text { Average indicator } \\
\text { of efficiency }\end{array}$} & \multicolumn{2}{|c|}{ Indicator of MAI } \\
\hline & Points & $\%$ & Points & $\%$ & Points & $\%$ & Points & $\%$ \\
\hline Very low & $0-13$ & $0-25$ & 4,4 & 2,10 & 61,2 & 8,40 & 38,5 & 68,0 \\
\hline Low & $14-26$ & $26-50$ & 16,9 & 16,80 & 80,1 & 21,00 & 34,5 & 71,0 \\
\hline Average & $27-39$ & $51-75$ & 35,4 & 79,00 & 84,9 & 66,40 & 39,9 & 76,2 \\
\hline High & $40-52$ & $76-100$ & 45,4 & 2,10 & 80,2 & 4,20 & 35,9 & 69,4 \\
\hline TOTAL & & & - & - & 76,6 & 65,10 & 37,2 & 70,7 \\
\hline
\end{tabular}

According to the received empirical data, the average rate of the indicator of metacognitive awareness was 37.1 points out of 52 , which is $70.7 \%$. More than $80 \%$ of respondents have showed the rate higher than average. As we can see, our results have coincided with the work of scientists who consider the average level of metacognitive involvement of students to be the most optimal. Also, some researchers have claimed that an excessively high level causes a high level of metacognitive abilities in combination with a low level of subject knowledge, which can absolutely lead to an overestimation of the student own knowledge and excessive self-confidence of students in efficiency of learning activities. Low or very low level of metacofgnitive awareness can lead the underestimation of the person's cognitive abilities, which would surely cause low efficiency of their learning activity (Karpov and Skityayeva, 2002).

Our next task was to interpret the results we obtained as a result of using the questionnaire "Metacognitive Awareness Inventory" by D. Everson \& S. Tobias. In particular, we have taken into account the results of only one of the four scales - the scale "Metacognitive involvement in activities". After processing the received empirical data, we have found out that the average value on this scale in the sample was $\mathrm{M}=9.68$.

On the next stage we have evaluated the indicators of metacognitive awareness with the use of G. Schraw \& R. Dennison's questionnaire "Metacognitive awareness". The method has also helped us to determine the level of student metacognitive monitoring skills, generalized in accordance with the cognitive processes in their learning activities. This questionnaire has included questions that determine knowledge about the regulation of cognitive activity of students in the process of self-regulated learning. The empirical data of the levels of metacognitive awareness of students in leraning activities has been presented at figure 2 .

It is obvious that a high level of student metacognitive awareness (metacognitive inclusion to the activities) has significantly prevaied in their learning activities. Empirical data has supported our conclusions that this age is sensitive in the development of student youth who learn to analyze their cognitive activity consciously and use self-regulation in their learning. Students at this age beging seeing themselves as the subjects of their own cognitive activity, and this consciousness allows them to intensify their learning activities. 


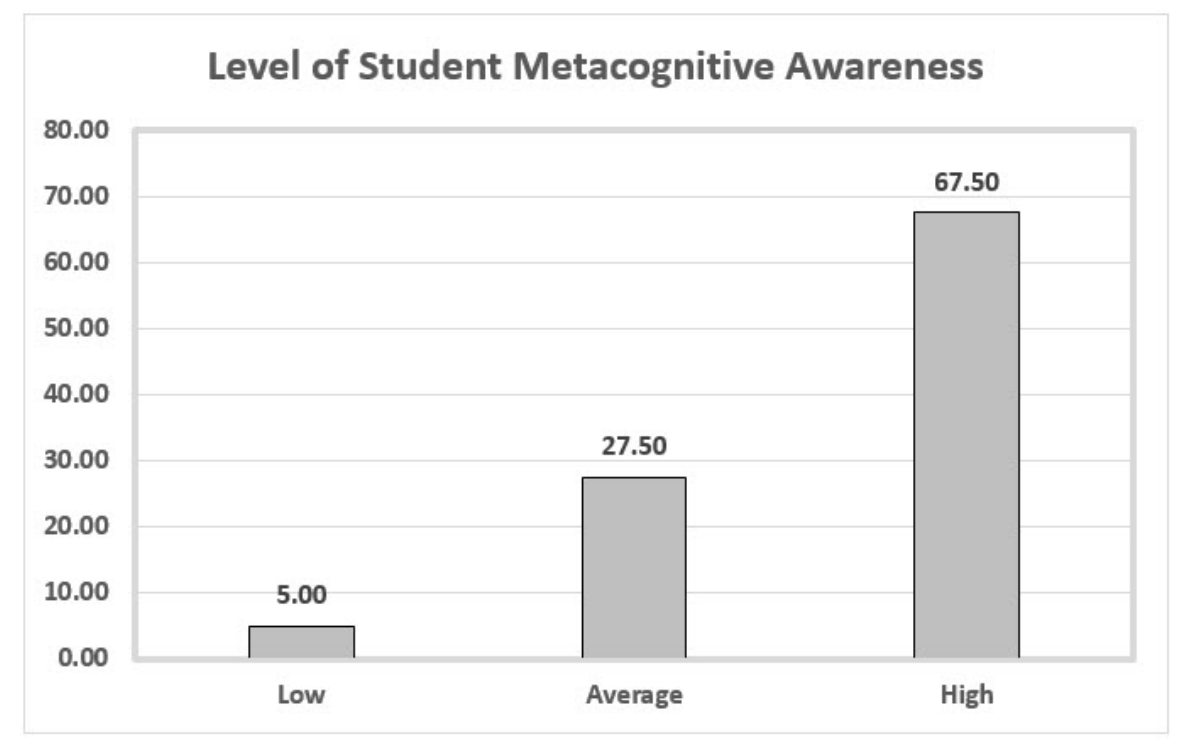

Figure 2. Levels of student metacognitive awareness according to the G. Schraw \& R. Dennison's questionnaire "Metacognitive awareness", $\%$

The next stage stage of the empirical study was conducted for determination of the correlations between the levels of metacognitive awareness (involvement in activities) of students and indicators of motivation of their educational self-regulation (Table 4). The correlations have been determined with the use of correlation analysis of the obtained data, the nature of the distribution of which allowed the application of the Pearson's linear correlation coefficient. As a result, the intensity of correlations between the levels of metacognitive awareness (involvement in activities) and the levels of motivation of self-regulated learning activities of students have been found out. It is obvious that a high level of metacognitive awareness (involvement) of students has a strong connection with internal (autonomous) motivation $(0,916)$ and identified self-regulation $(0,890)$. The average level of metacognitive awareness correlates with identified self-regulation $(0,904)$ and, to a lesser extent, with introjected self-regulation $(0,856)$. Correlation analysis has also demonstrated a close correlation between the external self-regulation of students' learning behavior and the low level of their metacognitive awareness (involvement in activities) $(0,804)$.

Table 4 students

Indicators of correlation between metacognitive awareness and academic self-regulation of Level of Metacognitive Level of Academic Self-Regulation

\begin{tabular}{|c|c|c|c|c|}
\hline \multirow[b]{2}{*}{ Awareness } & \multirow[b]{2}{*}{ External } & \multirow[b]{2}{*}{ Introjected } & \multirow[b]{2}{*}{ Identified } & \multirow{3}{*}{$\begin{array}{c}\text { Internal } \\
\text { (autonomous) } \\
0016^{* \star}\end{array}$} \\
\hline & & & & \\
\hline High & - & - & $0,890^{*}$ & \\
\hline Average & - & $0,856^{* *}$ & $0,904^{* *}$ & - \\
\hline Low & $0,804^{*}$ & $0,816^{\star *}$ & - & - \\
\hline
\end{tabular}
${ }^{*} p \leq 0,01,{ }^{* *} p \leq 0,05$

The data in Table 5 has confirmed that the students with a low level of metacognitive awareness have had a high level of external regulation (2,5\%), an average level of introjected regulation $(5,0 \%$, an average level of identified regulation (2,5\%) and a low level of intrinsic motivation (5,0\%). Such students are characterized by a mostly passive subjective attitude to their own learning activities. In general, in the organization of such activity, they rely on others, while having a low level of awareness of their own responsibility for the success of the results. They, as usual, do not strive for high results and awards. Most likely, students with a low level of metacognitive awareness would try to avoid aggravation of the conflict situation and punishment. It is difficult for such students to concentrate on any one type of activity, and priorities in their learning activities are mostly set depending on the circumstances of the surrounding learning environment. 
Balashov, E., Pasicichnyk, I. \& Kalamazh, R.(2021). Metacognitive awareness and academic self-regulation of HEI students, International Journal of Cognitive Research in Science, Engineering and Education (IJCRSEE), 9(2), 161-172.

Table 5

Indicators of correlation between the levels of metacognitive awareness and motivation of selfregulated learning of students, \%

\begin{tabular}{|c|c|c|c|c|c|c|c|c|c|c|c|c|}
\hline \multirow{2}{*}{$\begin{array}{l}\quad \text { Indicator of } \\
\text { academic self- } \\
\quad \text { regulation } \\
\text { Meta- } \\
\text { cognitive } \\
\text { awareness }\end{array}$} & \multicolumn{3}{|c|}{$\begin{array}{l}\text { External } \\
\text { regulation }\end{array}$} & \multicolumn{3}{|c|}{$\begin{array}{l}\text { Introjected } \\
\text { regulation }\end{array}$} & \multicolumn{3}{|c|}{$\begin{array}{l}\text { Identified } \\
\text { regulation }\end{array}$} & \multicolumn{3}{|c|}{$\begin{array}{l}\text { Internal } \\
\text { motivation }\end{array}$} \\
\hline & $\mathrm{L}$ & A & $\mathrm{H}$ & $\mathrm{L}$ & $A$ & $\mathrm{H}$ & $\mathrm{L}$ & A & $\mathrm{H}$ & $\mathrm{L}$ & $A$ & $\mathrm{H}$ \\
\hline Low & 0 & 0 & 2,5 & 0 & 5,0 & 0 & 0 & 2,5 & 0 & 0 & 5,0 & 0 \\
\hline Average & 5,0 & 42,5 & 5,0 & 5,0 & 52,5 & 7,5 & 2,5 & 27,5 & 5,0 & 10,0 & 30,0 & 15,0 \\
\hline Hiah & 7.5 & 27.5 & 10.0 & 25 & 22.5 & 5.0 & 12.5 & 22,5 & 27.5 & 2.5 & 20.0 & 17.5 \\
\hline
\end{tabular}

Students with an average level of metacognitive awareness (involvement in the activity) have an average level of external regulation (42,5\%), an average level of introjected regulation (52,5\%), an average level of identified regulation $(27,5 \%)$ and an average level of internal motivation $(30,0 \%)$. This category of students usually follows the rules and requirements of the educational environment and institution. They are accustomed to set an example in learning, diligently perform all learning tasks of teachers. For this group of students, the authoritative opinion of teachers is very important, and that is why they easily find common ground with teachers. They are quite versatile in their activities, as they are quite successful in learning and extracurricular activities. Students with an average level of metacognitive awareness try to use their internal resources effectively, but not excessively, because, having found the right solution to the problem, in the vast majority of cases they will consider this option sufficient.

Our last task has included execuition of correlation analysis with the use of the Pearson and Spearman's correlation coefficients. The average direct correlation $r=0.337^{\star}$, at a statistically significant level $p=0.05$ (according to the Pearson's coefficient) has been found between the indicators of metacognitive inclusion (according to the questionnaire "Metacognitive Awareness Inventory" by D. Everson \& S. Tobias) and the scale of metacognitive processes (the questionnaire of MAI G. Schraw and R. Dennison). Spearman's correlation coefficient between these indicators was $r=0.321$. That is, we have concluded that the higher the level of metacognitive awareness (involvement in the activities) of students, the higher the level of activity of their metacognitive processes in learning activities and vice versa.

Our empirical research has showed that a group of students with an average level of metacognitive awareness (involvement in activities) (according to the method of metacognitive involvement in activities "Metacognitive Awareness Inventory - MAl") has significantly prevailed among students. Respondents showed a higher-than-average level, and about $20 \%$ of respondents had a low level, which has allowed us to state the activity of the vast majority of students in conscious learning, activity in the meaningfulness and awareness of their own cognitive activity.

\section{Discussion}

Metacognitive awareness (involvement in activities) of students is one of the important components of metacognitive monitoring of students' self-regulated learning activities. It allows students to track their own intellectual and cognitive activities, select and use the right metacognitive strategies in learning, analyze and evaluate results. An urgent task for modern psychological science is the need to develop methodological tools for the study of metacognitive components that increase the effectiveness of students' learning activities.

One of the actual scientific problems in the framework of metacognitive orientation in recent years has been the study of the role of metacognitive processes in learning. Nowadays, the vast majority of the scientific studies are carried out in the framework of applied disciplines, such as age and educationa psychology, psycholinguistics, labor psychology, management psychology, developmental psychology, and so on. This has given the impetus to the development of psychodiagnostic tools that can quantify the ability of the subject of educational activities to metacognition (Karpov, 2012). In modern research on the problem of improving the performance of various activities (including student activities), many scientists have turned to studying the possibility of subjective use of metacognitive experience of the individual, such as metacognitive knowledge, experiences, strategies, experiences, skills (Balashov, 2019). The works of the psychologists in the field of metacognition in the learning process have showed a positive 
correlation between academic achievement and metacognitive awareness of students. When choosing metacognitive knowledge and skills, the formation of which should be included in the teaching process, it is necessary to take into account the current level of metacognitive involvement in the activities of students in the educational process (Pasichnyk et. al, 2014).

In the light of the results of our theoretical analysis and empirical research, with the help of statistical analysis, we have confirmed the hypothesis that there is a positive connection between the metacognitive awareness of students in their learning activities and their self-regulated learning. Empirical data from our study has showed that students with a high level of metacognitive awareness have an average level of external regulation, an average level of introjected regulation, a high level of identified regulation and an average level of internal motivation. Their behavior is mainly governed by a sense of choice; they have a high level of flexibility and creativity. Students in this group have an average level of identified regulation, and they try to regulate their learning behavior of their choice. Most often in their activities, they respect the rules and regulations, but they take into account the opinions of others in the context of their views. When performing tasks, they mainly consider various options for its implementation, using flexible and original approaches. They are mainly interested in educational activities, not paying attention to destructive factors. Most often, after a reasoned discussion, such students remain in their thoughts. Students of this type develop their metacognitive abilities, such as metacognitive knowledge, metacognitive monitoring, metamemory and metathinking. These results are consistent with some psychological studies about metacognitive involvement and monitoring, learning motivation (Flavell, 1976; Karpov, 2012; Balashov et al., 2020; Pasichnyk et. al, 2014; Pintrich and Schunk, 2002; Schunk and Greene, 2018; Pasichnyk and Maksymenko, 2010).

Metacognitive awareness can help mobilize the operational and behavioral resources of the individual for fostering self-regulation in learning, through which the intellectual activity the efficiency of learning activities is enhanced. The results of our empirical evaluation have proved that students with a high level of metacognitive awareness (involvement in activities) have high performance based on identified and internal self-regulated learning activities. The students of this type are more autonomous in conducting their self-regulatef learning activities, developing their metacognitive abilities, such as metacognitive knowledge, metacognitive monitoring, metamemory and metathinking.

Today, many of the scientists have focused at exploring the different factors determining the quality of metacognitive monitoring in self-regulated learning (Balashov et al., 2020; Karpov, 2012; Radchuk, 2015; Voloshyna, 2014). It has been distinguished that the students have developed reflexive skills at the metacognitive level, such as problem solution, appropriate efforts direction for the goals accomplishment, analysis of the own abilities to plan, execute, analyse and correct the own learning activities (Schraw and Dennison, 1994). Our study has proved that metacognitive awareness (inclusion to activities) has been confirmed to be closely interconnected with the components of academic learning motivation and self-regulation of students, supporting the previous statements of Schraw, Crippen and Hartleyet (2006), Schunk and Greene (2018), Khomulenko and Dotsevych (2014), Savchenko (2016), Tkachuk (2018).

The theoretical analysis and empirical data of our study have supported a conclusion that the definition and analysis of metacognitive awareness of students can be an effective tool for teachers who take into account the individual characteristics of students and properly build their activities to improve their metacognitive knowledge and skills. This is especially important in relation to students as subjects of their own cognitive activity. Such conclusions support the previous studies of Kreidun, Polivanova and Yavorovskaet (2018), Pintrich and Zuszo (2002), Schraw, Crippen and Hartley (2006), who emphasized the importance of metacognitive awareness in success of self-regulation of student learning process, and considered self-regulated learning at a higher educational institution as a factor of their academic motivation and professional self-efficacy of students.

\section{Conclusions}

Our empirical research has shown that the sample of students is dominated by a group with a high level of metacognitive awareness with an identified level of self-regulation of their learning activities. Correlation analysis with the use of the Pearson's correlation coefficient has proved that a high level of metacognitive awareness of students has a strong connection with internal (autonomous) motivation and identified self-regulation; the average level correlates with the identified self-regulation, and a little less - with the introjected; strong link between external self-regulation of students' learning behavior and low level of their metacognitive awareness (involvement in activities).

By comparing empirical data on the number of students with different levels of metacognitive 
awareness and different motives for self-regulatory learning, we have identified three groups of students: 1) students with low metacognitive awareness, who have a high level of external regulation, medium level of introjected regulation and low level of internal motivation; 2) students with an average level of metacognitive awareness, who have an average level of external regulation, an average level of introjected regulation, an average level of identified regulation and an average level of internal motivation; 3) students with a high level of metacognitive awareness, who have an average level of external regulation, an average level of introjected regulation, a high level of identified regulation and an average level of internal motivation.

Summarizing the results of theoretical analysis and the empirical data evaluation, we can conclude that the learning behavior of modern student youth has been dominated by dependent types of selfregulation. Students with external self-regulation of behavior are mainly characterized by a passive subjective position on their own learning activities. Introjected self-regulation of students determines their learning behavior based on the instructions of authoritative persons and increases the emotional dependence of students on such instructions. Students with predominant identified self-regulation are proactive, confident, independent who model their own patterns of behavior. Autonomous (internal) type promotes the development of metacognitive abilities of students, their creativity and self-organization, active subjective attitude to learning.

The results of the study have allowed to consider it possible in individual work with students to use questionnaires of metacognitive inclusion in activities (Metacognitive Awareness Inventory - MAl, authors G. Schraw and R. Dennison), as well as the Questionnaire "Metacognitive Awareness Inventory" by D. Everson \& S. Tobias. These techniques allow to identify students with very low and low levels of metacognitive awareness, to determine which metacognitive processes, important for the level of success, they do not use, but can potentially use. Also, the empirical data obtained by these two methods can increase the effectiveness of the use of relevant materials in the educational process based on the results of generalization of metacognitive elements that students use most often.

Determining the right balance of personal and motivational factors that are crucial for successful learning activities and determine the learning motivation of modern students is one of the most crucial and actual issues of modern higher education. Theoretical analysis of sources has shown that it is especially important for teachers to determine the relationship between metacognitive awareness (or involvement to learning activities) of students and their academic performance, which will develop metacognitive components that increase such academic performance.

\section{Acknowledgements}

Authors would like to express sincere words of gratitude to all participants of the research (students of the National University of Ostroh Academy).

\section{Conflict of interests}

The authors declare no conflict of interest.

\section{References}

Andrade, H. L., \& Heritage, M. (2017). Using formative assessment to enhance learning, achievement, and academic selfregulation. Routledge. https://doi.org/10.4324/9781315623856

Babikova, N., Maltseva, O., Startseva, E., \& Turkina, M. (2018). Research of Metacognitive Awareness of University Students. Bulletin of Mari State University, 12(3), 9-16. https://doi.org/10.30914/2072-6783-2018-12-3-9-16

Balashov, E. (2017). Psychological peculiarities and mechanisms of self-regulation in student learning activities. Scientific Notes of the National University of Ostroh Academy. Series "Psychology", 5, 5-13. https://doi.org/10.25264/2415-73842017-5-5-13

Balashov, E. (2019). Metacognitive experience as a precondition for development of self-regulation in learning activitites of students. Psychology of Personality, 1(10), 177-185. https://doi.org/10.15330/ps.10.1.177-185

Balashov, E. Pasichnyk, I., Kalamazh, R., Zdrobylko, T. (2020). Reflexive competence in metacognitive monitoring of learning activity of HEl students, International Journal of Cognitive Research in Science, Engineering and Education (IJCRSEE), (8), Special issue of Current Research and Trends in Cognitive Sciences 2020, 17-28. https://doi.org/10.23947/23348496-2020-8-SI-17-28

Bandura, A. (1997). Self-efficacy: The exercise of control. New York, NY: Freeman.

Brown, G., Andrade, H., \& Chen, F. (2015). Accuracy in student self-assessment: Directions and cautions for research. Assessment in Education. https://doi.org/10.1080/0969594X.2014.996523

Dweck C. S. (1999). Self-theories: Their role in motivation, personality, and development. Philadelphia: Psychology Press, Taylor \& Francis Group, 103-128. https://doi.org/10.4324/9781315783048.

Flavell, J. (1976). Metacognitive Aspects of Problem Solving. In: L. Resnick (Ed.), The Nature of Intelligence. Hillsdale, NJ: 
Balashov, E., Pasicichnyk, I. \& Kalamazh, R.(2021). Metacognitive awareness and academic self-regulation of HEI students, International Journal of Cognitive Research in Science, Engineering and Education (IJCRSEE), 9(2), 161-172.

Erlbaum, 231-236.

Flavell, J.H. (1987). Speculations about the nature and development of metacognition. In: F.E. Weinert \& R.H. Kluwe (Eds.), Metacognition, Motivation, and Understanding (pp. 21-29). Hillsdale, NJ: Lawrence Erlbaum Associates.

Karpov, A. \& Skityayeva, I. (2002). Psychology of reflexivity. Moscow: IP RAN.

Karpov, A. (2012). Interconnection of Learning and Metacognitive Characteristics of Personality. Yaroslavl Pedagogical Bulletin, 2(3) (Psychological and Pedagogical Sciences), 228-235. Retrieved from: http://vestnik.yspu.org/ releases/2012_3pp/51.pdf.

Kholodnaya, M. (2019). Psychology of Intellect: Paradoxes of Research. $3^{\text {rd }}$ edition. Moscow: UWrite.

Khomulenko, T. \& Dotsevych, T. (2014). Khomulenko, T. \& Dotsevych, T. (2014). Педагогічна рефрлективність як детермінанта розвитку метапам'яті викладача вищої школи [Pedagogical Reflexivity as a Determinant of Development of Metamemory of a High School Teacher]. Проблеми сучасної психологіï, 26, 595-606. Retrieved from: http://eehb. dspu.edu.ua/index.php/2227-6246/article/view/158850/158114.

Kreidun, N., Polivanova, \& O. Yavorovska, L. (2018). Satisfaction with Learning at a Higher Educational Institution as a Factor of Professional Self-Efficacy of Modern Students. Problems of Modern Education, 6, 37-41.

Pasichnyk, I. \& Maksymenko, S. (2010). Role of Cognitive-Style Characteristics of a Personality in the Process of Learning. Scientific Notes of the National University of Ostroh Academy. Series "Psychology", 14, 3-10.

Pasichnyk, I. Kalamazh, R. \& Avhustiuk, M. (2014). Metacognitive Monitoring as a Regulative Aspect of Metaknowledge. Scientific Notes of the National University of Ostroh Academy. Series "Psychology", 28, 3-16. Retrieved from https:// psj.oa.edu.ua/articles/2014/n28-ua/Pasisnik.pdf.

Pintrich, P. R. \& Schunk D. H. (2002). Motivation in education: Theory, research, and applications. Upper Saddle River, NJ: Merrill Prentice-Hall.

Pintrich, P. R., \& Zusho, A. (2002). The development of academic self-regulation: The role of cognitive and motivational factors. In A. Wigfield \& J. Eccles (Eds.), Development of achievement motivation (pp. 249-284). San Diego, CA: Academic Press. https://doi.org/10.1016/b978-012750053-9/50012-7

Poshekhonova, Y. \& Karpov, A. (2014). Motivational and Volitional Characteristics of Metaknowledge of HEI Students. Bulletin of DGPU, 4, 31-36.

Radchuk, H. K. (2015). Osoblyvosti samoaktualizatsii osobystosti studentiv v osvitniomu seredovyshchi vyshchoi shkoly [Peculiarities of Self-Actualization of Students' Personality in Educational Environment of Higher School]. Psykholohiia i osobystist-Psychology and Personality, 2(8), 2. 85-97.

Ryan, R. M., \& Connell, J. P. (1989). Perceived locus of causality and internalization: Examining reasons for acting in two domains. Journal of Personality and Social Psychology, 57, 749-761. https://doi.org/10.1037/0022-3514.57.5.749

Ryan, R. M., \& Deci, E. L. (2001). On happiness and human potentials: A review of research on hedonic and eudaimonic wellbeing. Annual review of psychology, 52(1), 141-166. https://doi.org/10.1146/annurev.psych.52.1.141

Savchenko, O. (2016). Osoblyvosti funktsionuvannia refleksyvnoi kompetentnosti yak tsilisnoi systemy [Peculiarities of functioning of reflexive competence as an integrated system]. Psykholohichni perspektyvy-Psychological Perspectives, 27, 222-236.

Schraw, G., \& Dennison, R. S. (1994). Assessing metacognitive awareness. Contemporary educational psychology, 19(4), 460-475. https://doi.org/10.1006/ceps.1994.1033

Schraw, G., \& Moshman, D. (1995). Metacognitive theories. Educational psychology review, 7(4), 351-371. https://doi. org/10.1007/BF02212307

Schraw, G., Crippen, K. J., \& Hartley, K. (2006). Promoting self-regulation in science education: Metacognition as part of a broader perspective on learning. Research in science education, 36(1), 111-139. https://doi.org/10.1007/s11165-0053917-8

Schunk, D. H., \& Greene, J. A. (2018). Historical, contemporary, and future perspectives on self-regulated learning and performance, in D. H. Schunk \& J. A. Greene (Eds.), Educational psychology handbook series. Handbook of selfregulation of learning and performance (p. 1-15). Routledge/Taylor \& Francis Group.

Tkachuk, O. (2018). Metacognitive monitoring in the system of metaknowledge. Theory and Practice of Modern Psychology, $4,158-162$

Tobias, S. \& Everson, H. T. (1997). Studying the relationship between affective and metacognitive variables. Anxiety, Stress \& Coping, 10:1, 59-81. https://doi.org/10.1080/10615809708249295

Voloshyna, V. (2014). To the Problem of Development of Metamemory Judgments. Scientific Notes of the National University of Ostroh Academy. Series "Psychology", 28, 150-159.

Yalanska, S. (2018). Psychology of Creativity: Textbook. Poltava: SIMON.

Yatsiuk, M. (2008). Adaptation of R. Ryan \& D. Connell's Questionnaire of Academic Self-Regulation (Causal dimension Scalell SRQ-A). Practical Psychology and Social Work, 4, 45-47.

Zasiekina, L. (2015). Psycholinguistic Approach to Diagnostics and Modification of Individual Negative Core Beliefs. East European Journal of Psycholinguistics, 2(1), 151-157. Retreived from https://evnuir.vnu.edu.ua/handle/123456789/9366 